\title{
Resolving Information Asymmetric and Social Network Theories Challenges in Crowdfunding Campaigns.
}

\author{
Francis Kwaku Kuma, Mohd. Effandi Bin Yusoff
}

To Link this Article: http://dx.doi.org/10.6007/IJARBSS/v11-i4/9628

DOI:10.6007/IJARBSS/v11-i4/9628

Received: 06 February 2021, Revised: 10 March 2021, Accepted: 25 March 2021

Published Online: 13 April 2021

In-Text Citation: (Kuma \& Yusoff, 2021)

To Cite this Article: Kuma, F. K., \& Yusoff, M. E. Bin. (2021). Resolving Information Asymmetric and Social Network Theories Challenges in Crowdfunding Campaigns. International Journal of Academic Research in Business and Social Sciences, 11(4), 89-102.

\section{Copyright: @ 2021 The Author(s)}

Published by Human Resource Management Academic Research Society (www.hrmars.com)

This article is published under the Creative Commons Attribution (CC BY 4.0) license. Anyone may reproduce, distribute, translate and create derivative works of this article (for both commercial and non-commercial purposes), subject to full attribution to the original publication and authors. The full terms of this license may be seen at: http://creativecommons.org/licences/by/4.0/legalcode

$$
\text { Vol. 11, No. 4, 2021, Pg. } 89 \text { - } 102
$$

Full Terms \& Conditions of access and use can be found at http://hrmars.com/index.php/pages/detail/publication-ethics 


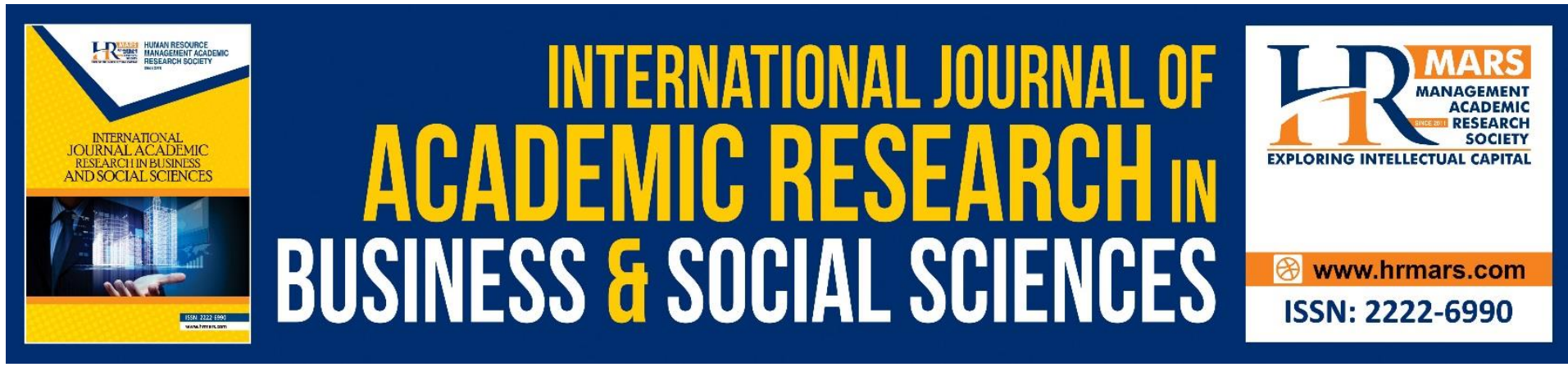

\title{
Resolving Information Asymmetric and Social Network Theories Challenges in Crowdfunding Campaigns.
}

\author{
Francis Kwaku Kuma \\ Universiti Teknologi Malaysia, Skudai, Johor Bahru, Malaysia, Department of Accountancy, \\ Koforidua Technical University, Ghana \\ Email: francis.kwaku.kuma@graduate.utm.my
}

Dr Mohd. Effandi Bin Yusoff

Universiti Teknologi Malaysia Skudai, Johor Bahru Malaysia

Email: effandi@utm.my

\begin{abstract}
Using Asymmetric Information and Social Networking theories the paper highlights the relevance of these two theories to crowdfunding. The study combines these theoretical perspectives with the practical aspects of startup companies raising finance using the crowd. The key concepts of these theories are critically considered and the study is conducted in the form of a review of the literature and expressing of opinion. Consequently, the experiential justification of the theories presented is not within the scope of this paper. The study is also limited generally to the field of crowdfunding as an alternate source of funding for start-up companies. We evaluate and discuss how lack of information between project initiators and backers can result in the project's inability to meet the project goal. We also consider how social network connection affects fundraising using the crowd. First, crowdfunding has some information difficulties because it involves the raising of funds using internet platforms. Second, the number of a founder's social network connections is associated positively with the capital raised from a project.
\end{abstract}

Keywords: Information Asymmetric, Crowdfunding, Social Networking, Startups

\section{Introduction}

The paper commences with an overview of the extant literature on the relevance of the theoretical aspect of crowd financing by reviewing the defining literature on Asymmetric Information and Social Networking theories in details. We also evaluate applications of these theories based on crowdfunding. In particular, we critically consider the key concepts of these theories and how they could be applied in practical terms. Existing research suggests that crowdfunding has become an alternative source of funding for most startup companies because of the inability of these startup companies to raise fund from banks and other traditional sources. This study offers several potential contributions to the literature on the emerging debate regarding the applicability of the two theories to the crowdfunding concept. 
The study conceptually synthesis these two theories to the concept of crowdfunding and advances the literature on crowdfunding in multiple ways. We demonstrate that information asymmetry and social network theories have a direct correlation with the workings of crowdfunding.

To guide our research, we draw on the review of existing literature on the broader definition of crowdfunding as a concept and then examine the relationship between this concept and its theoretical applications. Although we discuss the definition of crowdfunding as an alternative source of funding, we focus mainly on the conceptual idea of crowdfunding. While the study recognizes that crowdfunding can serve as an alternative source of funding, perhaps even more of concern is that lack of information between project initiators and backers can result in the project's inability to meet the project goal (Belleflamme et al., 2014).

\section{Literature Review}

Crowdfunding is gaining popularity in recent times and has caught the attention of scholars who have given various definitions to the concept (Cumming et al., 2019; Kassim et al., 2020). Evidence emerging from the literature suggest that there are dissimilarities in the definitions of crowdfunding among scholars. The study, therefore, presented the following prevailing definitions (Cumming et al., 2019; Block et al., 2018; Kuppuswamy \& Bayus, 2015a; Belleflamme et al., 2014; Mollick, 2014).

Belleflamme, Lambert, and Schwienbacher (2013) see crowdfunding as an open internet; call by project initiators for donations from the public in exchange for a reward from a future project. Steinberg (2012) emphasized crowdfunding as being alternate funding raising initiative in support of new business ventures. Mollick (2014) elaborated on the definition of crowdfunding by explaining that minimal contributions from a large group of people from the public could create significant capital for business start-ups. Agrawal et.al. (2011) added the dimension of geographical location to their definition. They are of the view that geographical location does not affect crowdfunding initiatives.

Regrettably, a critical look at the various definitions shows some gaps and it has therefore become difficult to grip the meaning of crowdfunding. First, Agrawal's (2011) position that crowdfunding has no geographical barriers is not entirely true concerning Sub Saharan Africa. Because social media and access to the internet coupled with erratic power supply and lack of regulations and laws in Sub Saharan African countries can act negatively on fundraising activities beyond the borders of these countries (Cambridge Centre for Alternative Finance, 2017). Following this argument, we can argue that geographical locations can somewhat adversely affect crowdfunding activities. Besides currency exchanges, lack of means of online payments etc. can also affect crowdfunding outside the geographical locations of backers (Berndt and Mbassana, 2016).

\section{Theoretical Frameworks}

Within this section, we evaluate and discuss how lack of information between project initiators and backers can result in the project's inability to meet the project goal. We also consider how social network connection affects fundraising using the crowd. First, crowdfunding has some information difficulties because it involves the raising of funds using internet platforms (Ahlers et al., 2015; Mollick, 2014). Second, the number of a founder's social network connections is associated positively with the capital raised from a project, Mollick (2014). 


\section{Information Asymmetric Theory}

Scholars have long recognized information-related challenges to the concept of crowdfunding so to address this gap we first describe the information asymmetric theory and its application to the concept of crowdfunding. We follow Akerlof (1970) comprehensive survey on how information between buyers and sellers can lead to ineffective results in certain markets (Akerlof, 1970). Akerlof (1970) argued that in many markets the buyer uses some market statistic to measure the value of a class of goods. He further explains that this information asymmetry gives the seller an incentive to sell goods of less than the average market quality. Interestingly Spence (1973) confirms the findings of Akerlof (1970) in his signalling theory, which states that one party (agent) credibly conveys some information about itself to another party (principal). Rothschild and Stiglitz, (1976) endorse the findings by using the insurance market as a basis for their argument on externalities caused by asymmetric information. Besides, Mattsson (2005) concludes that asymmetric information and signalling are valid concepts for describing the problems facing entrepreneurs and venture capitalists. This aligns with the claim by Samuelson (1984) that the presence of asymmetric information may preclude the possibility of reaching a mutually beneficial agreement.

Table 1 Empirical Results for information asymmetry and signalling theories

\begin{tabular}{ll}
\hline Author & Empirical findings \\
\hline Akerlof (1970) & $\begin{array}{l}\text { Information asymmetry gives a seller an incentive to } \\
\text { sell goods of less than the average market quality. }\end{array}$
\end{tabular}

Spence (1973) One party (agent) credibly conveys some information about itself to another party (principal).

Mattsson (2005) Asymmetric information and signalling are valid concepts for describing the problems facing entrepreneurs and venture capitalists

Ahlers et al. (2015)

Signalling: Funding success is related to financial transparency, amount of equity offered and human capital.

Bernstein et al. (2017)

Signalling: Information on human capital is important, while information on firm traction and lead investors is not.

\section{Source: Author's construction}

Table 1 presented the summary of the various views expressed by scholars on the effects information asymmetry and signalling theories have on crowdfunding. We recognize that these scholars presented their views from different perspectives. The study, therefore, aligns with the views expressed by Mattsson (2005). 
Figure 1 Information Asymmetry Theory

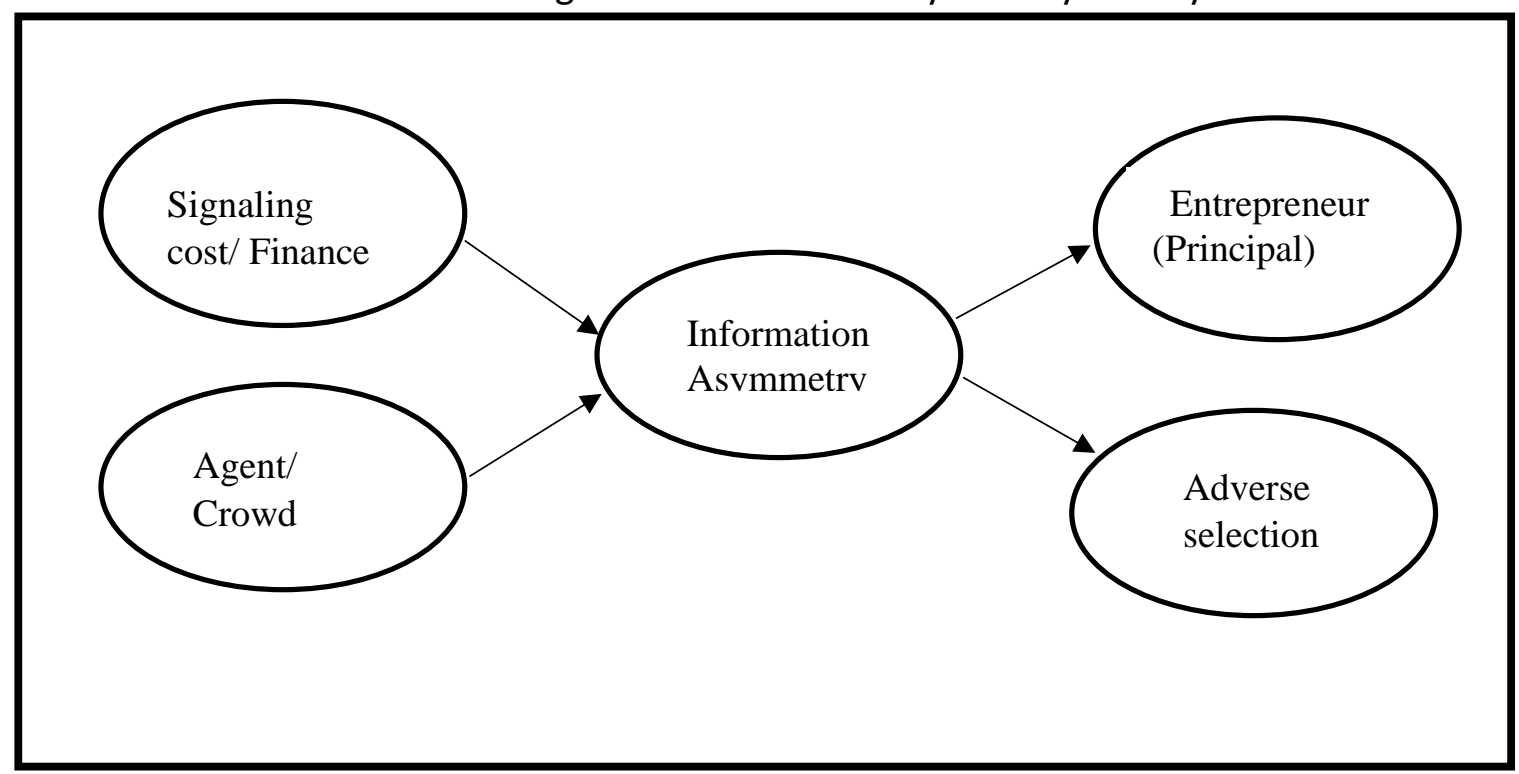

Source: Akerlof, (1970)

\section{Social Network Theory}

The study next examines the role of social networks in assisting in the raising of start-up capital using internet-based social media programs that make connections with investors and backers easier. Friedkin (1993) a longitudinal study found that personal influence grows stronger within more cohesive social networks than less cohesive ones. A further study conducted by Short, et al., (2018), confirm that networks can enhance a venture's legitimacy and reputation, and may thus serve as a signal of venture quality (Vismara, 2016). Other studies suggest that Networks and business linkages have become vital channels through which firms can access alternate funding for start-up businesses (McGee and Jones, 2019; Vismara, 2016; Agrawal et al., 2015a). In addition, networks, as well as social relationships, can provide access to valuable information. According to Granovetter (1983), this information tends to be more valuable than information accessed through formal channels, because it is more reliable and less redundant (Kauffman et al., 2019). Networks can also provide access to potential suppliers and customers, as well as to financial resources. Figure 1 shows how a lack of information could increase the cost of capital for both agents and principals. 
Figure 2 Social Network theory Model

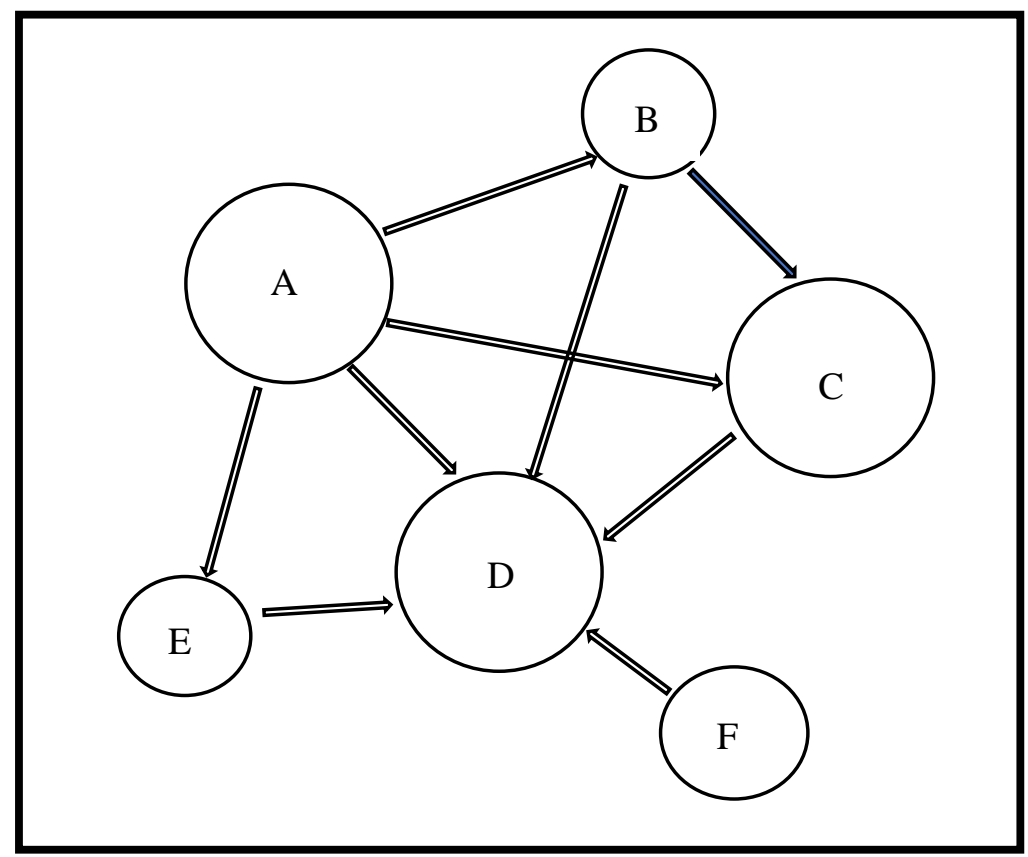

\begin{tabular}{|c|c|}
\hline & Legend \\
\hline Nodes & Social Network \\
\hline A & Friends/Families \\
\hline B & Clubs/ Academia \\
\hline $\mathrm{C}$ & Celebrity donors \\
\hline $\mathrm{D}$ & Fundraiser \\
\hline $\mathrm{E}$ & Media \\
\hline $\mathrm{F}$ & Community \\
\hline
\end{tabular}

Source: Author's construction

Figure 1 shows how a fundraiser (D) is socially connected to a variety of backers in the various spectrum of the society, which are indicated by the nodes in the diagram. Such a fundraiser has a high success rate for raising fund using the crowd (Kim and Hastak 2018).

\section{Discussions and Conclusions}

\section{Crowd funding and Information Asymmetry}

Although information asymmetries plague several sectors, we explore the possibility of how crowdfunding can be directly linked to information asymmetry theory. According to Ahlers et al., (2015) and Mollick (2014) crowdfunding has some information difficulties because it involves the raising of funds using internet platforms within a short period. Similarly, Belleflamme et al., (2014) also argue that because crowdfunding projects are usually at the early stages of development there is usually some doubts about the sustainability of the project. This doubt according to them is because the founder of the projects may have more information about the quality of the project than the potential backers. The backers therefore can be disadvantaged in terms of information regarding the credibility of the founder to produce and deliver the product or service as required (Ahlers et al., 2015; Mollick, 2014; Gerber et al., 2014).

To prevent the information gap Baum and Silverman, (2004) and Hsu, (2006) explain that potential backers can establish start-up features that may signal the viability of the start-up. They further hinted that an established stream of research following signalling theory Spence (1973) has analyzed how signaler attributes and signaler actions influence the likelihood of obtaining financial resources and achieving successful exit through initial public offerings (IPOs) and acquisition (Baum \& Silverman, 2004; Hsu, 2006). Many studies have offered insights into how signals reveal information to potential investors about the prospects of start-ups (Baum \& Silverman, 2004; Hsu, 2007). For instance, patents filed by technology 
start-ups can act as a credible signal of the underlying quality of the innovation and attract attention from private equity investors like venture capitalists and business angels (Baum and Silverman, 2004).

Distinctive from previous researches that focus on other aspects of equity crowdfunding Ahlers et al. (2015) explore the significance of signals in equity-based crowdfunding. Accordingly, they concluded that signals about the quality of start-ups and uncertainty levels relate positively to their funding success. Ahlers et al. (2015) focus especially on the parts played by the worth of equity on offer, viz., human capital and financial forecast in increasing the chances of raising adequate funding. In contrast, intellectual capital and social capital has no relation to the funding success of start-ups (Hiller, 2017). Figure 1 presents the information dissemination between the various actors such as the crowd (agent) and the entrepreneur (principal).

\section{Social Network theory and Crowdfunding}

Existing research suggests that one's support network size can be estimated by the number of friendship ties and signals of relational investment (Hui et al., 2014).

Social capital for investors is important for the financing of start-ups because of the network of ties between entrepreneurs and potential investors (Shane and Cable, 2002). Mollick (2014) confirmed the above assertion by stating that the relationship between proponents' social capital and project outcome is positive. Mollick (2014) further explains that the number of a founder's social network connections is associated positively with the capital raised from a project. Colombo et al. (2015) also state that the founder's social capital plays a critical role in attracting backers in the early days of a crowdfunding campaign. Ordanini et al. (2011) have also confirmed the role of social capital in donation-based crowdfunding.

Crowdfunding, therefore, offers an opening to apply social network analysis to inform decisions to connect and ask for support on social media. Scholars like Kauffman et al., (2019), found that social network size, and support for a project page, are correlated with crowdfunding success. Similarly, Short, et al.,(2018) argue that the people within the social network can spread information through social networks by easily sharing the information on the project. When posting projects on equity crowdfunding platforms, proponents often link their social network profiles to the platform accounts (Vismara, 2016).

A study conducted by Kuppuswamy \& Bayus (2015b) on the dynamics of reward-based crowdfunding argue that over a time contributions from backers for a project shows a ushaped pattern instead of a non-linear one. This is because the early and later stages of a project's live time attract more funding from funders (Kuppuswamy \& Bayus, 2015b). The findings of Kuppuswamy \& Bayus, (2015b) is similar for the various categories of projects, regardless of size or objectives goals or the success story. They attributed the pattern formation to the role played by family and friends in the early and final days of projects (Kuppuswamy \& Bayus, 2015b).

Furthermore, touching on herding behaviour Kuppuswamy \& Bayus (2015b) are of the view that funders are influenced by the amount of money raised during a particular funding campaign. Herding, therefore, plays a vital role in funding campaigns (Kuppuswamy \& Bayus, 2015b). This is because projects which can generate higher figures from backers outside social media and other institutions are likely to be fully funded (Mollick, 2013). Qiu,(2013) finds support for this argument by saying that projects, which featured prominently on the homepages of crowdfunding platforms, receive greater contributions from backers. Mollick 
(2014) on the other hand, pointed out that funding success is determined by social network size.

In a related, study on the role social networking plays in funding success on Peer to Peer crowdfunding platforms, Lin et al. (2013) came out with the view that it is easier for friends to have their loans funded and at a cheaper rate than other borrowers outside the social network (Lin et al., 2013). According to them friends in the social network play important role in spreading information about the credit quality to other potential borrowers. Similarly, regarding herding behaviour, a study by Andrews (2010) shows that strategic herding behaviour is prevalent among lenders such that potential funders follow the behaviour of their peers on social media and crowdfunding platforms. According to them herding is positively linked with loan performance and this is reflected in repayments of loan by borrowers. The results of strategic herding are confirmed by Zhang and Liu (2012) who stated that lenders use the lending decisions of their peers to measure the creditworthiness of potential borrowers. In addition, unfavourable loan characteristics such as low creditworthiness increase herding (Andrews, 2010).

On the issue of social capital, Colombo et al., (2015) argue that usually during the start of a campaign internal capital plays a key factor. According to them internal social capital is social capital within the crowdfunding platform (Colombo et al., 2015). Internal social capital can only be earned by taking part in the internal groups of the respective crowdfunding platforms (Colombo et al., 2015). They are therefore of the view that high internal social capital is linked with successful funding only with there is active participation in the crowdfunding activities. Besides, it is also a forecaster of the sum of money raised for a project, and this in turn facilitates successful funding (Colombo et al., 2015). 
Table 2 Empirical Results for P2P Crowdfunding

\begin{tabular}{ll}
\hline Author & Empirical findings \\
\hline Pope \& Sydnor (2011) & $\begin{array}{l}\text { Discrimination: Loan funding success is related to } \\
\text { the personal characteristics of the project } \\
\text { initiator }\end{array}$
\end{tabular}

Zhang \& Liu (2012)

Herding behaviour: Herding behaviour exists as funders infer creditworthiness of project initiator by peer lending decisions.

(Ravina, 2011)

Discrimination: Loan funding success is related to beauty and race.

Lin et al. (2013)

Social networks: Probability of getting funded is positively correlated with the internal social network size and quality.

Burtch et al. (2014)

Proximity \& culture bias: Funders prefer geographically proximate and culturally similar project initiators.

Herding behaviour: Herding behaviour exists and Andrews, (2010) is positively related to prior contributions and subsequent performance of a loan.

Sources: Author's construction

Table 2 presented and summarizes the various views presented by scholars on the social network theory and how it influenced crowdfunding.

\section{Contrasting views on social networks and crowdfunding}

Even though social networks play important role in the success of crowdfunding activities, other scholars have come out with some views, which work contrarily to these views.

Several other factors such as race, skin colour, age etc. can one way or the other affects the success of crowdfunding activities. For instance, Pope et al., (2011) in their study "What's in a Picture.....?" shows empirical evidence in support of the fact that pictures play a vital role in the success rates of loan listings. According to them, pictures on loan listing showing black women, elderly and overweight applicants are less likely to be successful. However, pictures on loan listing with white women with a military background have a high success rate (Pope et al., 2011). There is therefore racial discrimination against black women, overweight applicants and the aged regarding loan applications.

Similarly, taking it from the angle of the contributions of personal traits on funding success. Ravina (2012) pointed out that beauty and race influence the decisions of lenders. According to her, loan applications of beautiful women have a higher success rate in their loan application even though they may have poor credit rating, which could make them default in the loan repayments. In contrast, Burtch et al., (2014) presented evidence from their study 
on Kiva platform to show that lenders prefer to transact businesses with borrowers within their geographical boundaries and with people with whom they share similar cultures. They concluded that the dual roles of geographical distance and cultural differences affect lenders' decisions regarding the support for particular borrowers (Burtch et al., 2014).

\section{Challenges of asymmetric information and social network theories}

Although asymmetric information theory and social network theories are very useful tools, they have some challenges. Our discussion is thus based on our observations of the literature reviewed.

Firstly, Cawley and Philipson (1999) (life insurance) and Barros et al. (2010) (capital structure, 2010), have challenged the existence, evidence or practical duration of asymmetric information problems causing market failure. Likewise, some other scholars have also expressed similar views. They argue that in the real market not all participants are in the dark when it comes to information processing and that government involvement in the market can prevent prices from exactly reflecting known information, which can cause market failure (Mishra et al., 1998; Liu et al., 2017; Cox et al., 2018; Elliott, 2018; Kim and Hastak, 2018). However, Mishra et al. (1998) expressed concerns that customers usually do not have the opportunity to appraise a worth of a product accurately before buying due to information challenges. This is because usually, sellers misrepresent their product to gain undue advantage over potential customers. More often than not, they try to cheat or exploit their customers (Mishra et al. 1998).

Regarding social network theory, it has been established that crowdfunding project creators have challenges in determining the size of their social network (Hui et al., 2014; Agrawal et al., 2015; Vismara, 2016). More importantly, network size is class-based because celebrities and the elite in society have larger network sizes and have wealthy project backers compare to the underprivileged in society (Hardy 2013). Again, the elite in society- (celebrities, wealthy business tycoons etc.) could easily grow their network by having more wealthy people that can contribute to successful fundraising for a particular project. However, the under privilege often fails to grow this network of supporters because they are faceless people in society (Kauffman et al., 2019).

\section{Relation to other crowdfunding theory}

In this subsection, we very briefly considered the two theories under discussion concerning the agency theory.

More broadly, we interpret our views to suggest that the agency theory work in a similar sense as asymmetric information theory and it is applicable in the field of crowdfunding (Auronen, 2003). While we recognize the fact that this theory has been suggested in other works of literature we aim at contributing to this knowledge by exploring the possibility of its further application in crowdfunding. The study, therefore, offers some possible contributions to the literature. The agency theory explains the relationship between principals and agents in the business and it is mainly concern with solving difficulties that can occur in agency relationships (Hill, C. W., \& Jones, 1992; Hamscher et al., 1995; Pekmezovic Gordon Richard Walker, 2015). This theory according to Auronen (2003) is the first theory to reflect on the difficulties of asymmetric information theory. 
The agency theory works under the assumption that the principal and the agent have divergent interest and the appropriate way for the principal to limit this is to provide better incentive packages for the agent (Chod and Lyandres, 2018; Goebel, 2019; Martin et al., 2019; Pouryousefi and Frooman, 2019). In addition, the principal needs to pay the agent to spend a resource to make sure certain decisions the agent takes will not harm the interest of the principal (Martin et al., 2019). The stakeholders, which includes employees, communities, the public, customers, suppliers, and creditors, have some form of legitimate claim or interest in the business. It must be stated that the claim or the interest of the stakeholders is based on the size or proportion of stake in the business (Cuervo-Cazurra et al., 2019). In broader terms, stakeholders like the banks who provide loans to the business will want interest payment on their loans. Employees want better salaries, job security and good working conditions. Suppliers will want long-term contracts and stable contracts and prompt payments for their supplies (Chod and Lyandres, 2018). Investors who provide the resources in the form of capital to the business also want returns on their capital. Customers will want value for money. The state and the community that provide the business with infrastructure and location will expect corporate social responsibilities, tax payment and the protection of the environment

\section{Conclusion}

We studied the defining literature for asymmetric information and social network theories and their applications to crowdfunding as an alternate source of capital for startups. We also evaluated the challenges of both theories and their application to crowdfunding and offered the application of another theory. We are of the view that the applications of these theories as presented in our study help in developing the theories further and explain many important aspects of crowdfunding. It is clear from reviewed literature that these two theories have several useful applications, which are practical concerning crowdfunding.

In particular, we critically consider the key concepts of Asymmetric Information and Social Networking theories and their practical applications. We practically blend these two theories to the concept of crowdfunding and advances the literature on crowdfunding in multiple ways. We demonstrate that Information Asymmetry and Social Network theories have a direct correlation with the workings of crowdfunding. We make some theoretical contributions by providing novel insights into how information asymmetry and social networking theories play vital role in assisting project initiators to raise startup capital to commercialize their innovations. However, we suggest that the application of these theories to real crowdfunding should be methodically appraised.

\section{References}

Agrawal, A., Catalini, C., and Goldfarb, A. (2014) Some simple economics of crowdfunding, Innovation Policy and the Economy.

Agrawal, A., Catalini, C., and Goldfarb, A. (2015) 'Crowdfunding: Geography, Social Networks, and the Timing of InvestmentDecisions', Journal of Economics \& Management Strategy, 24(2, SI), pp. 253-274.

Ahlers, G. K. C., Cumming, D., Günther, C., and Schweizer, D. (2015) 'Signaling in Equity Crowdfunding', Entrepreneurship: Theory and Practice, 39(4), pp. 955-980.

Akerlof, G. A. (1970) 'The Market for "Lemons": Quality Uncertainty and the Market Mechanism', The Quarterly Journal of Economics, 84(3), p. 488.

Andrews, R. L. (2010) 'Electronic copy available at: http://ssrn.com/abstract=1596899', (713), 
pp. 1-32.

Anglin, A. H., Short, J. C., Drover, W., Stevenson, R. M., McKenny, A. F., and Allison, T. H. (2018) 'The power of positivity? The influence of positive psychological capital language on crowdfunding performance', Journal of Business Venturing. Elsevier, 33(4), pp. 470492.

Auronen, L. (2003) 'Asymmetric information: theory and applications', Seminar of Strategy and International Business at ..., pp. 1-35.

Barros, Carlos Pestana, Peypoch, N., Ibrahimo, M. V., and Barros, C. P. (2010) 'Capital Structure, Risk and Asymmetric Information: Portuguese Airports Theory and Evidence WP', School of Economics and Management Department of Economics Information : Theory and Evidence Capital Structure, Risk and Asymmetric Information: Theory and Evidence, p. 18.

Baum, J. A. C., and Silverman, B. S. (2004) 'Picking winners or building them? Alliance, intellectual, and human capital as selection criteria in venture financing and performance of biotechnology startups', Journal of Business Venturing, 19(3), pp. 411436.

Berndt, A., and Mbassana, M. (2016) 'East Africa Collaborative Ph . D . Program in Economics and Management East Africa Research Papers in Business, Entrepreneurship and Management Crowdfunding: The Beliefs of Rwandan Entrepreneurs East Africa Research Papers in Business ',.

Bernstein, S., Korteweg, A., and Laws, K. (2017) 'Attracting Early-Stage Investors: Evidence from a Randomized Field Experiment', Journal of Finance, 72(2), pp. 509-538.

Bilge, S. (2010) 'Beyond subordination vs. resistance: An intersectional approach to the agency of veiled muslim women', Journal of Intercultural Studies, 31(1), pp. 9-28.

Burtch, G., Ghose, A., and Wattal, S. (2014) 'Cultural differences and geography as determinants of online prosocial lending', MIS Quarterly: Management Information Systems, 38(3), pp. 773-794.

Cambridge centre for Alternative Finance. (2017) 'Crowdfunding in East Africa: Regulation and Policy for Market Development Reducing Poverty Through Financial Sector Development', Report, (January).

Cawley, J., and Philipson, T. (1999) 'An empirical examination of information barriers to trade in insurance', American Economic Review, 89(4), pp. 827-846.

Chod, J., and Lyandres, E. (2018) 'A Theory of ICOs: Diversification, Agency, and Information Asymmetry', SSRN Electronic Journal.

Colombo, M. G., Franzoni, C., and Rossi-Lamastra, C. (2015) 'Internal social capital and the attraction of early contributions in crowdfunding', Entrepreneurship: Theory and Practice, 39(1), pp. 75-100.

Cox, J., Nguyen, T., Thorpe, A., Ishizaka, A., Chakhar, S., and Meech, L. (2018) 'Being seen to care: The relationship between self-presentation and contributions to online pro-social crowdfunding campaigns', Computers in Human Behavior. Elsevier Ltd, 83, pp. 45-55.

Cuervo-Cazurra, A., Mudambi, R., and Pedersen, T. (2019) 'Subsidiary power: Loaned or owned? The lenses of agency theory and resource dependence theory', Global Strategy Journal, (October), pp. 1-11.

Cumming, D. J., Leboeuf, G., and Schwienbacher, A. (2019) 'Crowdfunding models: Keep-It-All vs. All-Or-Nothing', Financial Management, pp. 1-41.

Elliott, M. (2018) 'University of Cincinnati Law Review Trial by Social Media: The Rise of Litigation Crowdfunding', 84(2). 
Friedkin, N. E. (1993) 'Structural Bases of Interpersonal Influence in Groups', American Sociological Review, 58(6), pp. 861-872.

Goebel, V. (2019) 'Drivers for voluntary intellectual capital reporting based on agency theory', Journal of Intellectual Capital, 20(2), pp. 264-281.

Granovetter, M. (1983) 'The Strength of Weak Ties: A Network Theory Revisited', Sociological Theory, 1(1983), p. 201.

Hamscher, W., Kiang, M. Y., and Lang, R. (1995) 'Qualitative reasoning in business, finance, and economics: Introduction', Decision Support Systems, 15(2), pp. 99-103.

Hardy, W. (2013) 'How to perfectly discriminate in a crowd? A theoretical model of crowdfunding', University of Warsaw Faculty of Economic Sciences Working Papers, 16(101), pp. 1-28.

Hemer, J. (2011) 'A snapshot on crowdfunding', Enconstor, p. 39.

Hill, C. W., \& Jones, T. M. (1992) 'Stakeholder-Agency Theory Charles', Journal of Management Studies, 29(2), pp. 131-154.

Hiller, A. (2017) 'An Empirical Analysis of Crowdfunding in Sub-Saharan Africa', p. 209.

Hossain, M. (2016) 'Crowdfunding : Motives, Definitions, Typology and Ethical Challenges', (2011).

Hsu, D. H. (2006) 'Venture capitalists and cooperative start-up commercialization strategy', Management Science, 52(2), pp. 204-219.

Hui, J. S., Gerber, E. M., and Gergle, D. (2014) 'Understanding and leveraging social networks for crowdfunding: Opportunities and challenges', Proceedings of the Conference on Designing Interactive Systems: Processes, Practices, Methods, and Techniques, DIS, pp. 677-680.

'Investigating The Legal And Institutional Pre-Requisites for a Successful Implementation of Crowdinvestment In' (2014), (April).

Kauffman, R. J., Weber, T. A., and Editors, G. (2019) 'Special Section : Social Influence and Networked Business Interaction Special Section: Social Influence and Networked Business Interaction', Journal of Management Information Systems. Routledge, 36(4), pp. 1040-1042.

Kim, J., and Hastak, M. (2018) 'Social network analysis: Characteristics of online social networks after a disaster', International Journal of Information Management. Elsevier, 38(1), pp. 86-96.

Kuma, F. K., Miencha, I., Abrahams, A. Y., and Boadi, R. N. (2017) 'The Impact of Mobile Money Services on the Financial Transactions of Tertiary Students', International Journal of Innovative Research and Development, 6(7).

Lin, M., Prabhala, N. R., and Viswanathan, S. (2013) 'Judging borrowers by the company they keep: Friendship networks and information asymmetry in online peer-to-peer lending', Management Science, 59(1), pp. 17-35.

Liu, W., Beacom, A. M., and Valente, T. (2017) 'Social Network Theory IDU Peer Recruitment Dynamics and Network Structure in Respondent Driven Sampling View project', (September).

Martin, G. P., Wiseman, R. M., and Gomez-Mejia, L. R. (2019) 'The Interactive Effect of Monitoring and Incentive Alignment on Agency Costs', Journal of Management, 45(2), pp. 701-727.

Mattsson, J. (2005) 'Information asymmetry, market signaling and high-tech start-up financing', (Vc).

McGee, Z. A., and Jones, B. D. (2019) 'Reconceptualizing the Policy Subsystem: Integration 
with Complexity Theory and Social Network Analysis', Policy Studies Journal, 47(S1), pp. S138-S158.

Mishra, D. P., Heide, J. A. N. B., and Cort, S. G. (1998) 'Information Asymmetry and Levels of', XXXV(August), pp. 277-295.

Mollick, E. (2014) 'The dynamics of crowdfunding: An exploratory study', Journal of Business Venturing. The Author, 29(1), pp. 1-16.

Ordanini, A., Miceli, L., Pizzetti, M., Parasuraman, A., Gables, C., and Innovation, S. (2009) 'C : t c i is p', pp. 1-50.

Pekmezovic Gordon Richard Walker, A. (2015) 'From the SelectedWorks of Alma Pekmezovic Crowdfunding: Solving The Sme Funding Problem And Democratising Access To Capital'.

Pope, D. G., Sydnor, J. R., Pope, D. G., and Sydnor, J. R. (2017) 'What' s in a Picture ?: Evidence of Discrimination from Prosper . com What' $s$ in a Picture ? Evidence of Discrimination from Prosper . com', 46(1), pp. 53-92.

Pouryousefi, S., and Frooman, J. (2019) 'The Consumer Scam: An Agency-Theoretic Approach', Journal of Business Ethics. Springer Netherlands, 154(1).

Qiu, C. (2013) 'Issues in Crowdfunding: Theoretical and Empirical Investigation on Kickstarter', SSRN Electronic Journal.

Ravina, E. (2011) 'Love \& Loans: The Effect of Beauty and Personal Characteristics in Credit Markets', SSRN Electronic Journal.

Rothschild, M., and Stiglitz, J. (1976) 'Markets : an Essay on the Economics of', pp. 629-649.

'SamuelsonBargAsInfEc1984.pdf' (no date).

Schwienbacher, A., and Larralde, B. (2012) 'Crowdfunding of Small Entrepreneurial Ventures', SSRN Electronic Journal, 2010.

Shane, S., and Cable, D. (2002) 'Network ties, reputation, and the financing of new ventures', Management Science, 48(3), pp. 364-381.

Spence. (1973) 'I shall argue that the paradigm case of the market with this type of informational structure is the job market and will therefore focus upon it . By the end I hope it will be clear ( although space limitations will not permit an extended argument ) that a', The Quarterly Journal of Economics, 87(3), pp. 355-374.

'Stenberg-crowdfunding.pdf' (no date).

Vismara, S. (2016) 'Equity retention and social network theory in equity crowdfunding', Small Business Economics. Springer US, 46(4), pp. 579-590.

Zhang, J., and Liu, P. (2012) 'Rational herding in microloan markets', Management Science, 58(5), pp. 892-912. 